\title{
Truth Telling, Credibility, and the Story of the Self in the Diário da Navegação of Pero Lopes de Sousa
}

\author{
MARIA JOÃO DODMAN \\ York University
}

Cette étude se penche sur le Diário da Navegação de l'auteur portugais Pero Lopes de Sousa. Le Diário décrit un voyage de deux ans (1530-1532) et enregistre la tentative énergique du Portugal de consolider ses possessions brésiliennes. Tout comme d'autres documents portugais de voyage de l'époque, il présente un récit complexe et hybride qui emprunte à toute une gamme de styles d'écriture, de genres et de techniques littéraires. Au début, le Diário prétend être un journal de bord qui offre une information objective et fiable au sujet de plusieurs aspects du voyage: des vents aux courants, en passant par les habitants. Toutefois, je propose que le récit et l'ordre du jour du Diário est bien plus complexe. Au milieu des observations concrètes émerge un discours qui construit une image du héro portugais. De cette façon, le nouveau monde, ses habitants et les puissances européennes deviennent assujettis aux désirs portugais, et sont donc organisés en conséquence. Le narrateur, l'équipage et par extension tout l'empire, sont transformés en modèles exemplaires de protagonistes désintéressés, inventeurs d’un El Dorado brésilien. CCortugal gave New Worlds to the World" is a widely known axiom in
Portuguese culture. By the early sixteenth century this small European nation had established a profitable and extensive empire. The 1415 conquest of Ceuta, on the North African shore, signaled the initial steps that launched this small nation onto the world's stage as the first modern European overseas empire. In the century and more that followed, national pride was at an all time high, as the Portuguese revealed their prowess as gifted pilots, navigators, and explorers. By 1532, when Pero Lopes de Sousa wrote his Diário da Navegação, the Portuguese had established routes in all corners of the globe, exploring the African coast, opening the sea-route to India, making contact with Southeast Asia, and reaching Brazil. Portugal's discoveries were chronicled in a rich and 
varied literature that showed a keen desire to document the human and geographical alterity of these newly found lands. From the fifteenth to the seventeenth centuries, alongside the official accounts, many other records appear in the shape of letters, chronicles, travel logs, guide books, diaries, and relações. These writings were not an elitist activity, nor were they directed at a cultured public; often, they were written by common men, eyewitness participants in such adventures, for readers who were simply curious about the new world. The style of writing was a hybrid, not only of themes, but also of literary techniques and genres. ${ }^{1}$

The diary, or relação, of Pero Lopes de Sousa records a strenuous attempt by Portugal to consolidate its Brazilian possessions. Although the Portuguese had arrived in Brazil in 1500, they showed little interest in the land in the first decades following the optimistic Carta de Pero Vaz de Caminha a El-Rei D. Manuel sobre o Achamento do Brasil. ${ }^{2}$ This indifference derived from the fact that all of Portugal's resources were being exhausted on the lucrative trade in the Orient. Furthermore, as N. P. Macdonald points out, Brazil was a new kind of venture for the Portuguese, very different from Africa or Asia, as it lacked a local basis for trading and consequent settlement: "It would require the transfer of a large number of settlers to a distant land in every way different from their own, where they would be faced with innumerable hazards; in short, the building of a completely new world. This had not been foreseen and the country was quite unprepared for it." 3 By the early 1520s, however, the threatening presence of the Spaniards, plus the aggressive and habitual incursions of the French, led the Portuguese monarch to organize an expedition with the clear goal of colonization and territorial ownership. ${ }^{4}$ In addition to protecting sovereign territory, the crew would explore previously unknown areas in both northern and southern Brazil, make the first land distributions, and organize the first pockets of formal colonization. The most problematic area for the colonizers was in the south, particularly the Rio de la Plata, which the Portuguese contested with Spain. Thus, de Sousa's Diário would provide the earliest descriptions of the Rio de la Plata, carefully explored and documented by Pero Lopes de Sousa himself, who, with a crew of more than 30 men, spent over 30 days exploring the river.

The Diário da Navegação describes the entire two-year voyage (15301532), but the time frame of the actual writing of the manuscript is uncertain; most likely, it was not written on board. In any case, the Diário is the result of a profound preoccupation with a land that the Portuguese had barely begun 
to explore. The Diário long remained in manuscript; Brazilian historian Francisco Adolfo de Varnhagem first edited the document in 1839. ${ }^{5}$ The nineteenthcentury publication of the Diário had several political motivations: First of all, Varnhagem, in addition to being a scholar, was a diplomat with strong ties to both Brazil and Portugal. Second, a patriotic mood in Brazil fueled a new eagerness to rescue forgotten Portuguese heroes and founders of the new state. And third, both the narrator and the captain, his brother, belonged to the house of Bragança, the ancestral family of Pedro I and Pedro II, emperors of Brazil. ${ }^{6}$

The sixteenth-century expeditionary fleet had five ships and about 400 men. Among the eclectic crew of sailors, conquerors, tradespersons, exiles, and ambitious adventurers were Tomé de Sousa, Brazil's first vice-governor, and the first wave of Jesuit missionaries. The famous and well-regarded Martim Afonso, the narrator's brother, commanded. ${ }^{7}$ Reading the Diário, we see the fleet leaving Lisbon on December $3^{\text {rd }}, 1530$ and heading southwest. In the Atlantic crossing, the crew faces many hardships and endures endless storms. The fleet is also challenged on two occasions by French threats; first, near the cape of Santo Agostinho (northern Brazil, state of Pernambuco), and later near the island of Santo Aleixo (southern coast of Pernambuco). In both encounters, the French are defeated. The expedition makes several stops along the Brazilian coast, allowing the Portuguese to make contacts and gather important information about the land, the inhabitants, the resources, and the most desirable areas to develop and settle. Inland expeditions are also organized, such as the explorations of the rivers Maranhão and Plata, the latter commanded by the narrator himself. ${ }^{8}$ Along the way, the Portuguese succeed in fortifying several posts and important ports, among them Bahia de Todos os Santos, Pernambuco, Rio de Janeiro, and São Vicente. ${ }^{9}$ With the return to Portugal, on November 23, 1532, the Diário ends abruptly.

As the title of de Sousa's book, Diário da Navegação, indicates, the work purports to be a log. But upon "arrival" in Brazil, it becomes richer than a log, in ambition and scope, and takes on some of the traits of other genres, including the early modern European "relation," although there is no sign that the author had any literary mode in mind. Certainly the Diário soon deviates from its log mode. The author may well have had an earlier, official log in hand; and initially, as one might find in any log, there are chronological entries of assorted importance regarding the tides, skies, routes, and other relevant nautical information. Often, the entries are succinct, direct, and, as is typical of log entries, 
avoiding critical or interpretive statements. The brevity of these entries reveals the familiarity of the Portuguese with their environment. It is clear that the African Coast and the archipelagos of Cape Verde and the Canaries are wellknown territories. ${ }^{10}$ Pero Lopes de Sousa points out standard landmarks along the way - among others, the West African points, Cape Bojador, Cape Roxo, and Cape Sierra Leone - before the fleet ventures west onto the open Atlantic. Yet, amid mundane reporting, the narrator mentions a political encounter at Santiago, an island of Cape Verde: "here we found a vessel... and a small boat [chalupa] with Spaniards; and upon arriving they told us that they were on the way to the river of Maranhão [in Brazil]: and the Captain ordered them not to go to the said river as it belonged to the King, our Lord and it was within his demarcation line." ${ }^{11}$ This statement, unlike the typical log entry, reveals the crew's intention of enforcing royal claims. It also reveals something about Spain's reluctance to respect Portuguese sovereignty, straying from its theme of navigation to do so.

Unlike the typical log, the Diário was not written day-by-day, and might not even have been written on board. The author tends to use the past tense, as though the writing took place some time after the facts; there are also discrepancies in dates and extended stretches of time left unaccounted for. ${ }^{12}$ Nonetheless, Varnhagem argued that the Diário was written on board, late in the voyage back. Varnhagem bases his findings on the anticipatory tenses of an entry for February $5^{\text {th }}$, 1532: "and I was ordered to make preparations so I could leave for Portugal in these vessels and tell the king what we had accomplished." ${ }^{3}$ However, the errors in dates, the extended periods of silence, and the use of the past tense lead us to consider the other possibility that the entire document was written after the whole voyage, from recollection of events past, perhaps in Lisbon. In addition to the discrepancies mentioned, the opening remarks by the author offer yet another puzzling clue: "in the year of 1530, Saturday, third day of the month of December, I left this city of Lisbon." ${ }^{14}$ Clearly this passage, suggesting that the author is at the city, is problematic. But the use of the past tense shows that it was not written on board as the fleet was leaving Lisbon. Rather, the passage might have been added mid-voyage, for political reasons that hinged on the accuracy of the narrative, while at the same time, by anchoring the writer in the capital, giving him a bit more gravitas. We will return to this issue. 
For the initial part of the voyage the Diário attempts to be concise and objective. This remains the tone as the expedition reaches the cape of Santo Agostinho, now in the state of Pernambuco, where the entries usually restrict themselves to the several aspects of navigation. The familiarity of the Portuguese with this territory is clear, as the narrator highlights his knowledge of the currents and winds of Brazil's northern waters. ${ }^{15}$ Then, in a conscientious attempt to show events without expressing judgments and subjective opinions, the narrator relates a strange encounter with the natives at Bahia de Todos os Santos:

While we were in this bay in the middle of the river, fifty dug-outs from one side combated fifty dug-outs from the other. Each boat carries sixty men, and they [the boats] were all rigged with bulwarks painted like ours. And they fought from midday to sunset. The fifty boats from the side we were on were the winners; and they brought many of the others as prisoners, and they killed them with great ceremony, bound up with ropes, and after they were dead, they roasted them and ate them. And, if they didn't taste good, they wouldn't eat them and they would smoke them. And later they did the same with the wounded ones. ${ }^{16}$

Any reader would expect the narrator to elaborate on this gruesome scene. Yet de Sousa refuses to pass judgment and simply adds that "here the captain left two men to experiment with what the land yielded, and he left them with many seeds."17 Given this passage, de Sousa's entire text has been interpreted as objective, and therefore truthful..$^{18}$ In many documents of the time, Europeans express horror at such barbaric scenes, usually described in great detail, and label cannibalism a sin against humanity. ${ }^{19}$ Yet, unlike the Spanish, who failed to understand that "Christianization, like the export of any ideology or technology, can be condemned as soon as it is imposed, by arms or otherwise," ${ }^{20}$ the Portuguese, as if fully aware that they are on shaky grounds, are represented here as far slower to take the usual colonizer's approach. De Sousa's refusal to pass judgment does not produce a mere compilation of bare, observable facts. Rather, while he injects the narrative with authentic description, he also discloses information about the Portuguese. For instance, in the same cannibalistic scene, we are also told that the winners were those who had pledged allegiance to the Portuguese. Note, too, the size of this battle: each boat carried 60 men, 
and, says the Diário, there were 50 boats from each tribe. Faced with anything like such numbers, the Portuguese would have thought twice before acting or even expressing disapproval towards these powerful natives. The Diário documents their prudence. Yet other considerations, stemming from the narrator's assessment of these cannibals, might also have fed his silence regarding the gruesome scene. These warriors were not the seemingly simple-minded creatures encountered by Caminha 30 years earlier, but, to the writer's eye, rather more like the Portuguese. As de Sousa tells us, in their decoration the boats were reminiscent of those in Portugal, and, although they only used bows and arrows, the warriors in his account had some understanding of hierarchy and warfare. In addition, for de Sousa perhaps their most troubling characteristic, "the people of this land are all white." ${ }^{21}$ Peter Hulme notes a similar process with Columbus, in his literary reaction to the cannibals of the island of Bohio, described as: "well-armed, intelligent, cultured, inspiring fear [...] like the Spaniards." 22 De Sousa may have viewed these people in a similar fashion. Furthermore, the Portuguese were well aware of the troubles the Spaniards in the New World incurred in their treatment of the indigenous populations; the abuse was so notorious that Paul III in the 1537 bull "Sublimis Deus" would condemn Spanish behaviour and proclaim the indigenous people as human and capable of faith. As these were issues of great importance in the years before 1537, the Portuguese might have aimed to behave in such a way as to avoid a similar conflict with the Church.

In the cannibalistic scene, although surrounded by hordes of natives, the Portuguese do hold an important advantage: they have in their company a revered man of the land, "the Caramuru," "who had been in this land for twenty-two years, and he told us extensively about what was in the land." 23 This man, Diogo Alvares, now a well-known historical figure, was held in great esteem by both Portuguese and indigenous people. Such figures functioned as intermediaries between the two cultures; they were important for more than just relating information. They were responsible for the integration of local tribes into the colonial project - for Portugal, lacking manpower and wealth to exploit the new world, needed Indians to lay hold of Brazil. ${ }^{24}$ De Sousa is fully aware of the great importance of the intermediaries, and often records the interpreters that accompany the crew at all times: "while anchored, the captain sent a brigantine inland and with them a 'tongue' to see if there were people and to find out where we were." 25 These tongues are very valuable in establish- 
ing dialogue and relating important information, such as tribal identification: "and he spoke two or three words in Guarani, and the tongues he brought with him understood him." ${ }^{26}$ On another occasion, we will find in the brigantine three interpreters: Pedre Annes Piloto; Francisco de Chaves, and a man called "o Bacharel" [the bachelor], who had lived in the land for over 30 years. ${ }^{27}$ The go-betweens mentioned by de Sousa were all famous castaways, who, according to Bill Donovan, had an almost mythic stature in early Portuguese Brazil. Their knowledge and connections proved critical for Portuguese exploration. All had excellent connections, alliances, and even family ties due to marriages with the daughters of important tribe leaders. ${ }^{28}$ Perhaps the most important facet of this mission was that only these men, owing to their extensive connections, could help to establish a slave trade and perhaps find a Brazilian El Dorado. De Sousa notes, "Francisco de Chaves pledged that within ten months, he would return to said port [island of Cananéia, south-west of São Paulo] with four hundred slaves, all loaded with silver and gold." ${ }^{29}$ These men were also involved in trading with the Spanish and the French; ${ }^{30}$ thus, it was in the best interests of the Portuguese to develop relationships with these powerful intermediaries in the hope of binding them to the Portuguese Crown. As de Sousa remarks, when he records meeting the Caramuru and other important local figures, all happily welcomed the coming of the Portuguese. ${ }^{31}$ Indeed, in the years following the expedition, Portuguese colonists would rely heavily on the support of these men. ${ }^{32}$ Another rather practical reason to establish favourable bonds with these interpreters was to ensure the survival and security of the crew and to coax the indigenous people to support the interests of Portugal.

Although de Sousa attempts to present an idyllic image of best relations with the locals, contradictions in his text allude to the necessity of relying on the castaways. Perhaps the natives were less submissive than they had seemed initially. On one occasion, they refused to supply the expedition with much needed water. ${ }^{33}$ In the report of another incident, one cannot help noticing the anxiety of the Portuguese when faced with large numbers of natives, all of them strong, fast, and often fearless:

and they signed me to come in by way of a river that was near their tents. I sent a sailor swimming in to see if there was a good way in, and he looked it over and returned and told me that it was very narrow, and that we could not be safe among the people: who appeared to be many: - he 
thought maybe around six hundred men [...] and as soon as I saw this, I bid them farewell, and I gave them much merchandise, and they gave us fish. And they came after us, some swimming and some in dug-outs, for they swim better than dolphins. And we had the wind behind us blowing briskly - they swam as fast as we were going. These men are all very big, and muscular; and it seems like they have much strength. The women seem to have much strength. ${ }^{34}$

The crew, unable to cope with the vastness of the land and the strength of its people, and impeded by ignorance of local cultures and customs, could only succeed with the mediation of the castaways.

Yet, as the text progresses, the indigenous inhabitants, cannibals or otherwise, and the new world itself become a less prominent subject. The narrative, I argue, shifts focus and turns to the Portuguese themselves, more precisely to the actions of the narrator, to his quest for praise, heroism, survival, and even, in the worst case, martyrdom. The strategies used to transmit authenticity eyewitness accounts, citation of reliable sources, the nobility and prowess of the narrator - become tools that define, not the new world, but the self, the Portuguese hero. As the fleet makes its way south along the Brazilian coast, the entries become more elaborate and diverse; progressively, de Sousa's text moves from log to relation. As it evolves under its author's hand, the Diário more and more resembles a guide book "written by a cultured author, with a curiosity much superior to a common pilot's, [who] does not limit himself to the dry, yet precise, annotations of what he has happened to observe." ${ }^{35}$ Such descriptive and elaborate accounts are also in line with the relation [relação], for the vast majority of such documents associated with the discoveries (as noted earlier) have a rather hybrid, composite character and do not fit within a single genre or category. ${ }^{36}$

As we might expect of a relation, accounts of events are supported by the participation of the narrator as an eyewitness. But Pero Lopes de Sousa is an eyewitness of notable importance, a fact he highlights from the very beginning: "in the year of 1530, Saturday, third day of the month of December, I left this city, Lisbon, under the command of Martim Afonso de Sousa, my brother, who was the captain of the fleet and governor of the land of Brazil." ${ }^{37}$ With this concise introduction, first stating carefully both time and place, the narrator establishes his nobility as well as his relation to a captain of considerable fame 
and authority. Martim Afonso de Sousa was a distinguished member of the royal council, who, as a young man, had been trained in the arts of navigation, nature, cosmography and geography, knowledge that would further his future endeavours. ${ }^{38}$ As for the narrator, the captain's youngest brother, there is very little information. However, from the scarce references, it is clear that he was a notable man. A skillful navigator, already distinguished by his experience in Africa and in the archipelagos of Madeira and Açores, he may have also gone on an earlier expedition to Brazil (1526-1528) commanded by Cristovao Jacques. ${ }^{39}$ Indeed, the narrator's knowledge and seamanship are clear throughout the text. For instance, near the island of Santo Aleixo, he remarks, "in this area the waters run west-northwest: at certain times they run stronger [...] from March to October they run with greater force," or, "in this area, the navigation is uncertain: from truthful experience, to know if one is upwind or downwind of the island of Fernão de Loronha, when you are upwind you will see many birds, mostly frigate birds and black albatross and if you are to leeward you will see very few birds, only white albatross." ${ }^{30}$ In addition to his nautical experience, he is also praised for his military successes in Brazil, which gain him respect and will lead to posts on future important expeditions: among others, as commander-in-chief of a fleet to India in $1539 .{ }^{41}$

As Margarita Zamora reminds us, in the sixteenth and seventeenth centuries only an authority could guarantee truth, and historical facts "were not transformed into 'truth' until they were consecrated by the power of tradition or by the personal prestige of the author." ${ }^{22}$ Without a doubt, both the captain and the narrator are prestigious sources, guarantors of truth. The fact that Pero Lopes de Sousa chooses to open his Diário by introducing the nobility and status of the captain, his brother, recalls an important feature of historical discourse as examined by Roland Barthes. According to Barthes there are two shifters present in historical discourse: The first, the monitorial mode, corresponds to the evidential category, where the historian will choose to mention sources or witnesses' accounts. The second type "covers all those devices by which the writer declares a departure from or return to his itinerary, any explicit signpost to the organization of his discourse." ${ }^{33}$ As Barthes adds, "even chronological sequence of historical time may be disrupted by the organizational shifters which mark the onset of historical discourse." A performative opening might signal the onset of the discourse. ${ }^{44}$ These shifters do add a level of subjectivity; with the opening words of the Diário, they reveal an attempt to establish the superior 
rank of the whole voyage, commanded and elevated by Martim Afonso, and by extension or contagion, by the rank of the narrator himself. ${ }^{45}$ However, Pero Lopes de Sousa, throughout the text, continues to perform in an early modern manner contrary to Barthes's modern model of the objective author. ${ }^{46}$ Not only does he continue, in the relation mode, to inject himself in the narrative; he does so in a way that demonstrates his prowess, and honorable and heroic conduct, because "historical discourse is essentially a product of ideology, or rather of imagination [...] It is for this reason that the very notion of historical 'fact' has at various times seemed suspect." ${ }^{47}$ Artistry and imagination are key elements of any discourse, including those seemingly artless ones like de Sousa's that make an implicit claim to objectivity. Hayden White points out that:

like any philosophy of history, a historical narrative gains its effects as an explanation by its revelation of the deeper meaning of the events that it depicts through their characterization in figurative language [...] In the historical narrative the figurative element is placed to the interior of the discourse where it takes shape vaguely in the consciousness of the reader and serves as the ground whereon "fact" and "explanation" can be combined in a relation of mutual adequation. ${ }^{48}$

For its noble author, the relationship between the deeper meaning of the Diário and the impact on the reader would have been of considerable interest, as he is well aware of the expectations for this mission. Its success depended on the ability to rise above obstacles and lay the foundations of a Portuguese empire on this new, largely unfamiliar terrain. Therefore, the narrative, rather than focusing on the New World, tells a story of the self, building on a Portuguese ideal of enterprise. This aspect is present even in the initial pages of the Diário, where references to Portuguese prowess pepper an otherwise routine voyage. Amid the mundane observations of the sky and sea, one cannot miss the emphasis on hardship, owing to the many storms that curse the voyage: "the ocean was so rough, that if we had not had a bit of wind from the north, we would have been doomed"; "the wind became so strong that we could not use the sails [...] our foremast broke by the mast partner-chock." ${ }^{\prime 9}$ As well as damage to equipment, there is also human loss, hunger, and thirst, and there are those very desperate moments that lead the narrator to confess that: "we couldn't take the sea, which was very foul." ${ }^{50}$ Yet, defying all odds, the Portuguese triumph. 
In addition to their superior navigation skills, the Portuguese also reveal their moral superiority. The behaviour of other Europeans in Brazil does not pass unnoticed. The French in particular are singled out for failing to respect the land, its inhabitants, and, most importantly, Portugal's possessions. Their unrestrained exploitation of Brazil is obvious in their overloaded vessels, on several occasions captured by the Portuguese. De Sousa also quotes local witnesses who speak of the sack of the trading-station of Pernambuco by the French and its subsequent destruction. ${ }^{51}$ But, although the Portuguese manage to survive despite these attacks, the Diário reveals their enduring suffering, which sometimes requires the intervention and patronage of the divine: "in the caravel they [the French] did not kill or wound any of my men, and I was very grateful to God, our Lord." ${ }^{52}$ Divine intervention is no subtle theme, but a constant presence that guides and protects the fleet. Near the island of Cananea on the Brazilian coast, de Sousa credits our Lady with clearing away the fog that had been distressing the mission, and again, near the island of Gorriti, it is our Lady and her blessed son who save the fleet from an otherwise certain death..$^{53}$ Such expressions of gratitude to divine power do appear frequently in almost all accounts of voyages and expeditions. Here the narrative departs from the $\log$ mode. In these instances, the document resembles much more the popular Portuguese tales of shipwreck, sharing with that genre the common themes of the uncooperative sea, storms, attacks, the cruelty of enemies, and divine intervention. ${ }^{54}$ In such tales, the divine also determines the fate of the expedition when it faces shipwreck. ${ }^{55}$ De Sousa's expedition, in spite of several difficulties, never goes under, as if this venture had the blessing not only of the king, but also of the heavens.

For de Sousa, signs of divine favour and accounts of the moral conduct of the Portuguese help to support both a mission that competes with the French and Spaniards, and hopes that exemplary conduct will win the favour of the Church. Greenblatt's Renaissance Self-Fashioning comments on the plasticity of European identities and on the use of concrete models, often Christian, to construct a convenient version of a self. ${ }^{56}$ Thus, Pero Lopes de Sousa carefully constructs for his expedition tale a Portuguese identity rooted in the best of Christian conduct. As proof of their exemplary behaviour, well aligned with the duties of religion and the imperatives of justice and civil existence, the narrator catalogues the many advantages that the Portuguese bring to the land and its people. Upon the creation of the very first village of São Vicente, the 
captain "arranged everything within the works of justice, from which the people derived a great deal of consolation, seeing that their towns were populated and that they had laws and sacrifices [proper rituals], and that they celebrated marriages, and lived in touch with skilled crafts... and had all the other benefits of a safe and sociable life." ${ }^{57}$

In religion and morals, the narrator is no exception. If anything, he is the model for all to emulate, a noble, selfless, and strong leader. For instance, when ordered by the captain to defeat two French ships near the island of Santo Aleixo (southern coast of Pernambuco state), he takes charge and highlights his role in the subsequent victory. While there were many men involved in the battle, the narrator stresses the "I": "I spent all night with the plumb-line in hand"; "I arrived near the ship, and before I could fire, they fired on me with two shots: before nightfall, I fired three shots at them [...] and the wind became so strong from the east south-east that I could only play the light artillery."58 Yet, on other occasions, the narrator does the opposite. When the Portuguese quail, he distances himself from the group: "the sailors were afraid, because the sea was a very dangerous thing." 59 The narrative's version of de Sousa maintains his composure even when taking arms against a sea of troubles. While the crew panics during a particularly dangerous storm, he takes charge, and saves all:

It was so tumultuous on board that we couldn't understand each other: I ordered the people below, under cover, and I headed to the bow, and I decided to test fortune and attempted to round the headland, because if I didn't round it there would be nowhere for the ship to run ashore except on naked rock and there would be no saving us. And so we went, and with the grace of Our Lady and her blessed Son we rounded it. ${ }^{60}$

De Sousa is the perfect image of the warrior-knight or soldier-saint hero, the champion of the spread of Christianity. ${ }^{11}$ And, in sixteenth-century mode, he takes on the heroic greatness of famous navigators and explorers; by defying all dangers, these new heroes become the "intellectual obsessions" of a new age, immersed in an innovative spirit of inquiry and exploration. ${ }^{62}$

Indeed, the emulation of exemplary behaviour does bring the Portuguese rewards. The narrator points out the cordial relationships between the Portuguese and the natives, and sends a clear message that Portuguese presence is needed: "The principal men of this land came to show their obedience to the 
captain; and they brought many supplies and they celebrated with many festivities and dances, showing much pleasure that we had come here." ${ }^{63}$ On another occasion, natives in six almadias approach the crew, unarmed, and hug the Portuguese with much delight. ${ }^{64} \mathrm{Gift}$ exchanges help strengthen these relationships. As back in Portugal, gift-giving serves readily to establish and maintain bonds, symbolic of friendship and solidarity ${ }^{65}$ Many examples of these exchanges appear throughout the text:

And they [the Portuguese] continued until they found a great king, lord of all those lands, and he gave them much honor, and came back with them until they reached the captain; and he brought him much crystal, and told him the news that in the river of Paraguay there was a lot of gold and silver. And the captain gave him much honour and many gifts and sent him back to his land. ${ }^{66}$

The Portuguese resort again to gift exchange when they encounter an unknown tribe during the exploration of the river; here, faced with many fearless, armed men, the Portuguese offer little bells, crystals, and beads. This small gesture pays ample reward as the natives "were so happy and showed so much pleasure that they seemed to be beside themselves." ${ }^{17}$ In this apparently naive and merry exchange of gifts there is a hierarchy that signals Portuguese superiority and dominance. For instance, meeting a great lord of these lands, the Portuguese simply dismiss him and send him back home. In the other tale, the indigenous people's reactions to trinkets evidences their child-like behaviour, more in line with that of the welcoming natives met by Pero Vaz de Caminha 30 years earlier. But, most importantly, this southern tribe is described as receiving the Portuguese with open arms: not only do they show great pleasure at their presence; they are also willing to furnish the basic necessities. ${ }^{68}$ Much like the cannibals up north, these southerners quickly reveal their willingness to serve the Portuguese; but unlike the former, they appear simple-minded, and much more manipulable. This trait stands out in the latter part of the narrative, as the old simple log entries now acquire a critical and less objective tone. Near the cape of Maldonado, de Sousa says of the indigenous people:

the men of this land are very muscular and big; their facial features are ugly: they wear their hair long; some pierce their noses and fill the holes 
with very shiny pieces of copper: they all wear skins; and they sleep out in the open where night catches them... they are very sad; and most of the time they cry. When any of their relatives die, they cut their fingers, a joint for each relative; and I saw many elders that only had their thumbs.... they do not enjoy anything, and there is nothing that can bring them joy... they sigh constantly, and their only expression is sadness; and it does not seem to me that they enjoy any other thing. ${ }^{69}$

Unlike the people of Bahia de Todos os Santos, these more southerly natives not only lack cultured behaviour, they also pose no great threat. This passage in the Diário represents a turning point in the narrative; it reveals a much less precarious situation and signals easy conquest. In this instance, to read de Sousa, the conduct of the Portuguese follows the same logic used by Columbus, as Greenblatt describes him, "emptying out the category of the Other" where "the Other exists only as an empty sign, a cipher." ${ }^{70}$ In fact, de Sousa reveals a shocking detail, proving once and for all the comfort level of the Portuguese and their colonizing attitude towards these southerners: while searching for firewood, the crew finds the burial grounds where the remains of 30 dead and their most intimate objects were laid to rest. The graves were marked with many pieces of wood and the narrator notes: "I ordered that all the wood be taken from the graves: I ordered that they be brought for us to make a fire, so to prepare two deer that we killed." ${ }^{11}$ This casual sacrilege is a clear proof that the Portuguese, in spite of rivals, have claimed full ownership of the land and its people.

Not only is this land readily conquered because its people can easily be subdued, but also, contrary to the tone of the rest of the Diário, the South is filled with infinite wonders that surpass all expectations and meet all European desires. The abundance in the Rio de la Plata is described as follows:

the fish is the most beautiful and tasty that I have ever seen. The water here was completely fresh, but the sea was so wide that it did not seem to me that it was a river; in the land there was much deer [pampas deer or perhaps guanaco] and game... the land has much honey and it's very good: and we found so much that we desired for nothing. And there are thistles, which are very good sustenance, and [our] people much enjoyed eating them. ${ }^{72}$ 
On more than one occasion, the narrator reveals the awe of the Portuguese at the beauty of the land:

\begin{abstract}
we were all astonished by the beauty of this land, and we were in such awe that we couldn't even think about our return... the air of this river is so good that none of the meat, nor the fish go rotten; and in full summer, we were killing deer and we had meat that was 10, 12 days old, with no salt, and no foul smell. The water of the river is very tasty; warm in the morning, very cold at midday; and the more a man drinks, the better is tastes. One cannot speak, nor write, the things about this river, and the good qualities of it, and of the land. ${ }^{73}$
\end{abstract}

This idyllic paradise now evokes Caminha's letter of 30 years earlier, where the crew, awed, presents a land that is habitable, hospitable, bountiful and without the least hint of danger from its local inhabitants.

The sharp difference in tone in the latter part of the Diário is most likely linked with the changing royal attitudes regarding Brazil. Three letters from the king (all dated November of 1530) indicate significant changes by João III towards Brazil. The new policy now intended territorial occupation, and the captain Martim Afonso de Sousa was ordered to implement these new directions; the king, eager to take the territory, charged the captain to claim all present and future land found in the name of Portugal. ${ }^{74}$ There were conflicting views of Brazil's role. As Luís de Albuquerque aptly points out, this largely unknown and difficult territory did not hold the appeal of an India or Africa; ${ }^{75}$ the prospect of treasure was absent, the dream of El Dorado belonging solely to the Spanish. Thus, the Diário had the added pressure of meeting not only the crown's desires, but also to present a land that, in the absence of treasure, could compete and present an equally attractive dream. Therefore, the Diário puts forward a world of possibilities: a North with allies and promises of slaves and precious stones, and a South with infinite beauty and resources where dominance appears easy.

As expected, the Portuguese enacted the rituals of possession by naming several locals, and placing padrões to assert Portuguese territorial rights. Perhaps one of the most revealing possessions is the Monte de São Pedro, ${ }^{76}$ at today's Montevideo, as the narrator tells us, "I discovered and named it... the land around the hill is level and very beautiful."77 This entry is significant not only because of its language, but also because it is one of the very few entries that 
gives not only day and month, but also year. Clearly, the intentions of the Portuguese in the South are not geared toward making connections, as in the North. Here, along the disputed border with Spain, the goal was to claim ownership. Accordingly, no longer concise and objective, the Diário's later entries evidence a concern for territorial demarcation, where "taking possession is principally the performance of a set of linguistic acts: declaring, witnessing, recording."78

Beyond the pages of the Diário, we learn that, while de Sousa returns to Portugal, captain Martim Afonso stays behind until 1533, on the island of São Vicente (in southern São Paulo), establishing the first proper villages. Under his command, villages do take root and the seeds of Portuguese domination are sown. Also under his command, the first sugar plantation is established. Both the narrator and his brother were rewarded for their success. In fact, in September of 1532 the king decided to settle the entire Brazilian coast, in part thanks to the accomplishments of the captain and his crew. ${ }^{79}$ As for when the Diário was written, all evidence points to a later date and to the brothers' desires for fame and recognition. Although they were granted an ample helping of land themselves, neither brother ever returned to Brazil, as if the dream sold in the Diário was not one that they themselves believed. Pero Lopes de Sousa died prematurely a few years later, ${ }^{80}$ but Martim Afonso de Sousa went on to become governor of Portuguese India (1547), and even wrote an autobiography (1557). Much like the Diário the autobiography is infused with a healthy dose of suffering, self-praise, and affirmations of unquestionable loyalty to crown and realm. Yet, according to Albuquerque, there are many instances where Martim Afonso de Sousa distorts the tale, for he was in fact a ruthless opportunist with a strong sense of entitlement. ${ }^{81}$ His brother Pero, our Diário's author, although perhaps less cultured, was no more honourable; upon leaving India, he had acquired a reputation for ferocity and cruelty. ${ }^{82}$

By the end of its composition, the Diário da Navegação is much more than a mere log; it is a hybrid narrative. Faithful to its chronological order, and likely using an actual ship's journal as template, it presents itself as a log, but oscillates between concise, dispassionate entries and richer passages that report on larger spaces and describe the conditions of the land and its people, all filtered through eyewitness accounts of participants willing to please the king, the captain, and themselves. In the text, all truth and credit accrues to the Portuguese. Their suffering, moral superiority, and exemplary conduct make them heroic and true proprietors of a splendid new land. And, while this docu- 
ment uses the relation mode to offer many descriptions of first or early contact between the Portuguese and the Brazilian landscape and its population, it also offers considerable information about the ambitious narrator himself, a highly visible protagonist in his own emergent chronicle.

\section{Notes}

1. Literatura dos Descobrimentos e da Expansão Portuguesa (Lisbon: Editora Ulisseia, 1993), by M. Ema Tarracha Ferreira, offers a detailed summary of the rich and varied textual production associated with the Portuguese discoveries and expansion. The hybrid nature of these documents is also noted in the introduction; written to document the maritime experience, these documents did not obey the literary and aesthetic canons of the time, and so offered a new vision of the world and humanity.

2. This glowing letter is filled with idyllic landscapes and splendid people. According to Lisa Voigt "such scenes of peaceful intermingling and 'merrymaking' between Europeans and Amerindians have earned Pero Vaz de Caminha's letter to king Manuel a foundational position in the Brazilian literary canon and contributed to notions of the distinctive benevolence of Portuguese colonization": see Voigt's "Por andarmos todos casy mesturados': The Politics of Intermingling in Caminha's Carta and Colonial American Anthologies," Early American Literature 40.3 (2005), p. 407. Jerry M. Williams remarks that this "approach to intermingling allows Caminha to see the Indians not so much as anomalous humans but more as part and parcel of the vast synthesis of God's creation," in "Pero Vaz de Caminha: the Voice of the Luso-Brazilian Chronicle," Luso-Brazilian Review 28.2 (1991), p. 65. Eduardo Dias even claims that "the letter is marked by a deep sense of humanism. There is no patronizing attitude towards the Indians. The author seems to identify with them, even to show a spirit of brotherhood. ... a true democratic outlook radiates from this first encounter," in "Brazil's Birth Certificate: the Letter of Pero Vaz de Caminha," Pacific Coast Philology 27.1-2 (1992), p. 14.

3. N. P. Macdonald, The Making of Brazil: Portuguese Roots 1500-1822 (Brighton, UK: Book Guild, 1996), p. 69.

4. By 1526 the Portuguese claims to Brazil were seriously threatened by other European powers. In 1526, D. João III was informed that a fleet of ten French ships was sailing to explore the new world. That voyage caused a violent confrontation. 
1526 also marks the exploration of the Rio da Prata [Rio de la Plata] by a Spanish fleet under Cabot. See Jaime Cortesão, A Colonização do Brasil (Lisbon: Portugália Editora, 1969), pp. 57-66. In fact, several Europeans, merchants or exiles [degregados], already lived in Brazil and served as go-betweens or brokers in the early brazilwood trade. These men played a pivotal role between local tribes and Europeans, and, one that did not always meet or serve the interests of the Crown. While the Portuguese attempted to curb the power of these men, the French encouraged their own men to infiltrate and live among the Indian groups. See A. Metcalf, GoBetweens and the Colonization of Brazil (Austin: University of Texas Press, 2005), pp. 59-62.

5. Varnhagem used three different manuscripts; one that he had in his possession, one that belonged to the count D. Francisco de São Luís, and the oldest at the Biblioteca Nacional da Ajuda in Lisbon.

6. See J. P. Leite Cordeiro's "Introduction" to Pero Lopes de Sousa's Diário da Navegação (São Paulo: Obelisco, 1964), pp. 5-11.

7. Martim Afonso was only 30 years old at the time of this voyage. He was a nobleman, descendant of D. Afonso III, and a man of "unbreakable character, austere, brave and tenacious, one of those incarnations of the ideal Portuguese type" [carácter inquebrantável, austero, bravo e pertinaz - uma dessas incarnações do tipo ideal do português] (Cortesão, p. 68). My translation.

8. The river of Maranhão crosses three of the Brazilian federal districts: Federal, Goiás and Tocatins. The famous river Plata (Prata in Portuguese) now separates Uruguay and Argentina.

9. The port of Bahia de Todos os Santos is in northern Brazil, in the state of Bahia; the post of Pernambuco, also in the north of Brazil was located on the mouth of the river of Igaraçu, near the island of Itamaracá; Rio de Janeiro is of course the capital; São Vicente, the coastal city on the southern state of São Paulo, was the first Portuguese settlement of southern Brazil, and founded by the captain of this expedition, Martim Afonso de Sousa, in 1532.

10. The author reveals his familiarity with the area by using certain verbs such as recognize (reconhecer) that clearly point out that these are not new environments: "we recognized that it was the island of Tenerife" [reconhecemos ser a ilha de Tenerife], "we recognized that it was the island of Sal" [reconhecemos ser a ilha do Sal]. See Pero Lopes de Sousa, Diário da Navegação, "Introduction" by J.P. Leite Cordeiro (São Paulo: Obelisco, 1964), pp. 14-15. The Diário has not been translated; all translations are mine. 
11. "Aqui achamos hûa nao... e hûa chalupa de castelhanos; e em chegando nos disseram como iam ao Rio de Maranham: e o capitam I. lhe mandou requerer que eles nam fossem ao ditto rio; porquanto era de el-rei nosso senhor e dentro da sua demarcaçam" (De Sousa, p. 16). The author here refers to the division of the world established in the Treaty of Tordesillas (1494), which shared the still unexplored world between Spain and Portugal.

12. For instance, the author jumps from Monday, March 11 to Saturday and dates it March 12: De Sousa, p. 27.

13. "Me mandaram fazer prestes para que eu fosse a Portugal nestas naos a dar conta a elrei do que tinhamos feito" (De Sousa, p. 72).

14. "Na era de 1530, sabado 3 dias do mes de dezembro, parti desta cidade [d]e Lixboa" (De Sousa, p. 13).

15. De Sousa, p. 24.

16. "Estando nesta bahia no meio do rio pellejaram cincoenta almadias de hûa banda, e cincoenta da outra; que cada almadia traz secenta homens, todas apavezadas de pavezes pintados como os nossos: e pellejaram desd'o meio dia até o sol posto: as cincoenta almadias, da banda de que estavamos surtos foram vencedores; e trouxeram muitos dos outros captivos, e os matavam com grandes cerimonias, presos por cordas, e depois de mortos os assavam e comiam. como se acham mal nam comem, e poem-se ao fumo; e assi pelo conseguinte os que são feridos" (De Sousa, pp. 28-9).

17. "Aqui deixou o capitam I. dous homôs, para fazerem experiencia do que a terra dava, e lhes deixou muitas sementes" (De Sousa, p. 29).

18. Commenting on the introductory pages of the Diário, J. P. Leite Cordeiro refers to the somber, dry and objective nature of the document, in De Sousa, pp. 5-6.

19. Tzvetan Todorov mentions the disgust and attempts to eradicate such behaviours by the Spaniards. Indians caught in these practices were typically burnt alive. See Tzvetan Todorov, The Conquest of America, the Question of the Other, trans. Richard Howard (New York: Harper \& Row, 1984), p. 179.

20. Todorov, p. 179.

21. "A gente desta terra he toda alva" (De Sousa, p. 28).

22. Peter Hulme, "Tales of Distinction: European Ethnography and the Caribbean," in Implicit Understandings. Observing, Reporting, and Reflecting on the Encounters Between Europeans and other Peoples in the Early Modern Era, ed. Stuart B. Schwartz (Cambridge, UK; New York, NY: Cambridge University Press, 1994), pp. 157-97, esp. p. 167. 
23. "Nesta bahia achamos hum homem portugues, que havia vinte e dous anos que estava nesta terra; e deu rezam larga do que nella havia" (De Sousa, p. 28).

24. Bill M. Donovan, "Discovery and Conquest of the Brazilian Frontier," in Portugal, the Pathfinder: Journeys from the Medieval Toward the Modern World, 1300-ca. 1600, ed. George D. Winius (Madison: Hispanic Seminary of Medieval Studies, 1995), pp. 229-46, esp. pp. 230-1.

25. "Estando surtos mandou o capitam I. hum bergantim a terra, e nelle hûa lingua para ver se achavam gente, e para saber onde eramos" (De Sousa, p. 38).

26. "E fallou-nos 2 ou 3 palavras guaranís, e entenderam-as os linguas que levava" (De Sousa, p. 59).

27. De Sousa, pp. 38-40.

28. Diogo Alvares for instance had several wives and numerous children, and some men from Martim Afonso's expedition married into his ample family. See Donovan, p. 232.

29. "Francisco de Chaves se obrigava que em 10 meses tornara ao dito porto com 400 escravos carregados de prata e ouro" (De Sousa, p. 40). According to Jaime Cortesão, this would have been a major reason for the captain Martim Afonso to stay behind until 1533. Inspired by the recent conquests of Cortez, Martim Afonso must have had similar ambitions. These were shattered in early 1533, when the captain received notice that the entire expedition had been killed by the Carijó tribe of $\mathrm{Cu}$ ritiba. See Cortesão, pp. 78-9. On the topic of slavery, Metcalf also notes that when Gandavo writes his history of Brazil in the 1570's, the well-established slavery that he refers to is not African, but indigenous, a practice that starts soon after Cabral's landing in 1500; again, as Metcalf adds, "the actions of go-betweens at all levels established slavery, Indian and African, as a fundamental part of the Portuguese colonization of Brazil" (Metcalf, pp. 157-8).

30. Metcalf, p. 76 .

31. De Sousa, p. 28.

32. Metcalf, pp. 55-88.

33. De Sousa, p. 23.

34. "E elles acenavam-me que entrasse para hum rio, que junto das suas tendas estava. Mandei la hum marinheiro a nado, para ver se tinha boa entrada: e veo e disse-me que era muito estreito, e que nam podiamos estar seguros da gente, que era muita: que lhe parecia que eram 600 homês [...] Como vi isto me despedi delles; e lhes dei muita mercadoria; e elles a nós muito pescado. E vinham apoz de nós, hûs a nado e outros em almadias, que nadam mais que golfinhos; e da mesma maneira nós com 
vento á popa muito fresco: - nadavam tanto quanto nós andavamos. Estes homês sam todos grandes e nervudos; e parece que tem muita força. As molheres parece que tem muita força” (De Sousa, pp. 61-62).

35. "O seu autor, com uma cultura e, sobretudo, com uma curiosidade muito superior ao piloto corrente, não se limita à anotação seca, embora precisa, do que lhe ia sendo dado observar" in Luís de Albuquerque and Francisco Contente Domingues, Dicionário de História dos Descobrimentos Portugueses, vol. 1-2 (Lisbon: Caminho, 1994), vol. 1, p. 352. My translation.

36. The Diário does appear under other classifications; it is labelled a guide book in the Dicionário de História da Colonização Portuguesa no Brasil, coordinated by Maria Beatriz Nizza da Silva (Lisbon Editorial Verbo, 1994), and as a "relação da navegação" in Luís de Albuquerque and Maria do Anjo Ramos, ed., Martim Afonso de Sousa (Lisbon: Publicações Alfa, 1989).

37. "Na era de 1530, sabado 3 dias do mes de dezembro, parti desta cidade de Lixboa, debaixo da capitania de Martim Afonso de Sousa, meo irmão, que ia por capitam de hûa armada e governador da terra do Brasil" (De Sousa, p. 13).

38. Martim Afonso de Sousa went on the have a colonial career so substantial that Camões praised him in his Lusíads. To reward his work in Brazil, the king granted him the capitanias of São Vicente and Rio de Janeiro. See Albuquerque and Domingues, Dicionário de História dos Descobrimentos Portugueses, vol. 2, pp. 1003-5.

39. "Pero Lopes, only twenty years old, had already an authority and an experience out of the ordinary" (Albuquerque and Domingues, Dicionário de História dos Descobrimentos Portugueses, vol. 2, p. 1005).

40. "Nesta paragem correm as águas a loesnoroeste: em certos tempos correm mais; desde março até outubro correm com mais furia; Assi que nesta paragem a pilotagem he incerta: por experiencia verdadeira, para saberdes se estais de barlavento ou de julavento da ilha de Fernão de Noronha, quando estais de barlavento vereis muitas aves as mais rebiforcados e alcatrazes pretos e de julavento vereis mui poucas aves, e as que virdes serão alcatrazes brancos" (De Sousa, pp. 19-20).

41. Albuquerque, Martim Afonso de Sousa, p. 135. Pero Lopes dies on a return voyage, in 1540, wrecked near the island of Sao Lourenço.

42. Margarita Zamora, "Historicity and Literariness: Problems in the Literary Criticism of Spanish American Colonial Texts," MLN 102.2 (1987), pp. 337-8.

43. Roland Barthes, "Historical Discourse," in Structuralism: A Reader, ed. Michael Lane (London: Jonathan Cape, 1970), p. 146. 
44. Barthes identifies religious invocations and prefaces as forms of performative openings, in Barthes, pp. 145-55.

45. If we compare this text to the one written 30 years earlier by Pero Vaz de Caminha, we note a very different opening; Caminha's text is addressed to the king, and the narrator immediately establishes his inferior rank and humble writing, a feature not present in de Sousa's text.

46. "Where the author seeks to stand aside from his own discourse by systematically omitting any direct allusion to the originator of the text: the history seems to write itself” (Barthes, p. 148).

47. Barthes, p. 153.

48. Hayden V. White, "Historicism, History, and the Imagination," in Tropics of Discourse: Essays in Cultural Criticism (Baltimore: Johns Hopkins University Press, 1978), p. 115.

49. "E o mar andava tam grosso, que se nos nam ventara hum pouco de vento norte foramos de todo perdidos; $E$ ventou com tanta força que nem podiamos com a vela [...] nos arrebentou o mastro do traquete pelos tamboretes" (De Sousa, pp. 16-17).

50. "Nam podemos sofrer o mar, que era mui feo" (De Sousa, p. 30).

51. De Sousa, pp. 16, 21, 22, 24.

52. "Na caravela me nam mataram nem feriram nenhum homem, de que dei muitas graças ao senhor Deus" (De Sousa, p. 22). Here we find another clear indication that the author is writing from recollection of events past, and not offering the day-to-day annotations of the typical log.

53. De Sousa, pp. 39, 46.

54. Manuel Simões, A Literatura de Viagens nos Séculos XVI e XVII (Lisbon: Comunicação, 1985), pp. 15-17.

55. Simões, p. 15.

56. "the cultural system of meanings that creates specific individuals [governs] the passage from abstract potential to concrete historical embodiment" in Stephen Greenblatt, Renaissance Self-Fashioning: from More to Shakespeare (Chicago: University of Chicago Press, 2005), pp. 2-4.

57. "E pôz tudo em obra de justiça, de que a gente toda tomou muita consolaçam, com verem povoar villas e ter leis e sacrefícios, e celebrar matrimonios, e viverem em comunicaçam das artes... e ter todolos outros bens da vida sigura e conversavel" (De Sousa, p. 71).

58. "Fui toda a noite com o prumo na mão; Cheguei á nao, e primeiro que lhe tirasse, me tirou dous tiros: antes que fosse noite lhe tirei tres tiros [...] e de noite carregou 
tanto o vento lessueste, que nam pude jogar senam artelheria meuda" (De Sousa, pp. 21-22).

59. "Os marinheiros houveram mui gram medo, por o mar ser cousa mui perigosa" (De Sousa, p. 27).

60. "Era tam grande revolta na não que nos nam entendíamos: mandei meter toda a gente debaxo da coberta, e eu me fui á proa, e determinei de fazer experiencia da fortuna, e me por a ver se podia dobrar a ponta; porque se a nam dobrava nam havia onde varar, senam em rocha viva, onde nam havia salvaçam: assi fomos, e prouve a nossa senhora e ao seu bento filho, que a dobramos" (De Sousa, pp. 45-46).

61. The figure of Christ crucified nourished the concept of suffering for a great cause, while the long history of wars with Islam developed an idea of Christian chivalry. The concept of heroism now came to embody, in its primary phases, valour, loyalty, adventure, and a strong will. K. L. Johar, Christopher Marlowe: a Study in the Renaissance Concept of Heroism (Meerut: Shalabh Prakashan, 1988), p. 16.

62. Johar, pp. 21-23.

63. "Os principaes homês da terra vieram fazer obediencia ao capitam I.; e nos trouxeram muito mantimento, e fizeram grandes festas e bailos; amostranto muito prazer por sermos vindos aqui" (De Sousa, p. 28).

64. "E saíram-me 6 almadias, e todos sem armas, senam vinham com muito prazer abraçar-nos" (De Sousa, p. 61).

65. Andrew Cowell, The Medieval Warrior Aristocracy: Gifts, Violence, Performance, and the Sacred (Woodbridge, UK; Rochester, NY: D. S. Brewer, 2007), p. 7.

66. "E foram até darem com um grande rei, senhor de todos aquelles campos, e lhes fez muita honra e veo com eles até os entregar ao capitam; e lhe trouxe muito christal, e deu novas como no Rio de Peraguay havia muito ouro e prata. O capitam lhe fez muita honra, e lhe deu muitas dadivas e o mandou tornar para as suas terras" (De Sousa, p. 36).

67. "Ficaram tão contentes e mostraram tamanho prazer, que parecia que queriam saír fóra o seu siso" (De Sousa, p. 52).

68. De Sousa, p. 52.

69. "A gente desta terra sam homês mui nervudos e grandes; de rosto sam mui feos: trazam o cabelo comprido; alguns delles furam os narizes, e nos buracos trazem medidos pedaços de cobre mui lucente: todos andam cobertos com pelles: dormem no campo onde lhes anoitece... sam mui tristes; o mais do tempo choram. Quando morre alguns delles segundo o parentesco, assi cortam os dedos por cada parente hûa junta; e vi muitos homês velhos, que nam tinham senam o dedo polegar... senam 
suspiravam sempre; e nunca faziam modo senam de tristeza; nem me parece que folgavam com outra coisa" (De Sousa, p. 67).

70. Stephen Greenblatt, Marvelous Possessions: the Wonder of the New World (Chicago: University of Chicago Press, 1991), p. 60.

71. "Mandei tirar todolos páos das sepulturas: mandei os trazer para fazermos fogo, para se fazer de comer 2 veados, que matámos" (De Sousa, p. 67).

72. "O pescado o mais formoso e sabroso, que nunca vi. A agua ja aqui era toda doce; mas o mar era tam grande que me nam podia parecer que era rio: na terra havia muitos veados e caça... na terra ha muito mel e muito bom: e achavamos tanto que o nam queriamos: e ha cardos, que he mui bom mantimento, e que a gente folgava de comer" (De Sousa, pp. 51-52).

73. “Todos eram espantados da formosura desta terra, e andavamos todos pasmados que nos nam lembrava tornar... o ar deste rio he tam bom que nehûma carne, nem pescado apodrece; e era na força do verão que matavamos veados, e traziamos a carne 10,12 dias sem sal e nam fedia. A agua do rio he mui saborosa; pela manhã he quente, e ao meio dia he muito fria; e quanta o homem bebe, quanta melhor se acha. Nam se podem dizer nem escrever as cousas deste rio, e as bondades delle e da terra" (De Sousa, pp. 58-59).

74. Albuquerque, Martim Afonso de Sousa, pp. 141-43.

75. Albuquerque, Martim Afonso de Sousa, p. 141.

76. Actual Cerro of Montevideo.

77. De Sousa, pp. 49-50.

78. Greenblatt, Marvelous Possessions, p. 57.

79. There are indications in the document that the king was kept informed on the progress of the mission. For instance, on an entry dated February 5, 1532, the author states that the captain was to stay behind with the necessary people needed for the villages, but the others were to return to Portugal. See de Sousa, p. 72.

80. However, although the references to de Sousa are minimal before 1530, he gained some notoriety after this trip, not only in Portugal, but also in France, Italy, and with the Church. See Albuquerque and Domingues, Dicionário de História dos Descobrimentos Portugueses, vol. 2, p. 1005.

81. Albuquerque, Martim Afonso de Sousa, pp. 81-84.

82. Albuquerque and Domingues, Dicionário de História dos Descobrimentos Portugueses, vol. 2, p. 1005. 